\title{
RANĚ NOVOVĚKÁ REPUBLIKA UČENCŮ A WWW: DIGITÁLNÍ METODY ZKOUMÁNÍ UČENECKÝCH KORESPONDENČNÍCH SÍTÍ
}

\author{
VLADIMÍR URBÁNEK
}

\section{EARLY MODERN REPUBLIC OF LETTERS AND THE WWW: DIGITAL METHODS OF RESEARCHING SCHOLARLY CORRESPONDENCE NETWORKS}

This article explores the international database projects, which deal with scholarly correspondence in the sixteenth to eighteenth century and investigate the Early Modern republic of letters. The author evaluates these databases' potential contribution to research of subjects related to Bohemia. Using the example of John Amos Comenius's correspondence, whose catalogue is part of the Early Modern Letters Online database, this contribution shows ways of using digital tools for its research and interpretation.

Keywords: republic of letters - scholarly correspondence - Early Modern Era - database - John Amos Comenius

DOI: $10.14712 / 23365730.2019 .4$

\section{Res publica literaria a učenecká korespondence jako specifický pramen}

Učenecké korespondenci jako specifickému pramenu dějin vzdělanosti, dějin vědy, dějin myšlení či nejnověji intelektuálních dějin byla věnována badatelská pozornost již od 19. století. ${ }^{1}$ Vznikaly pokusy zprístupnit zejména korespondenci kanonických postav různých národních dějin či dějin různých oborů nebo velkých duchovních proudů, např. osobností typu Erasma Rotterdamského pro Holandsko, ${ }^{2}$ Melanchthona či Leibnize pro Německo, ${ }^{3}$ Voltaira pro Francii, ${ }^{4}$ Tychona Brahe pro Dánsko, ${ }^{5}$ Linnéa pro Švédsko, ${ }^{6}$ či Komenského pro české země. ${ }^{7}$

1 Tato studie vznikla v rámci projektu GA ČR 14-37038G „Mezi renesancí a barokem: Filosofie a vědění v českých zemích a jejich širší evropský kontext“ řešeného ve Filosofickém ústavu Akademie věd ČR.

2 Percy Stafford Allen (ed.), Opus epistolarum Des. Erasmi Roterodami, 12 vols., Oxford 1906-1958.

3 Corpus Reformatorum, Serie I, Philipp Melanchthon, Opera Quae Supersunt Omnia, I-XXVIII, Halle 1834-1860; Ján KvaČAla (Hg.), Neue Beiträge zum Briefwechsel zwischen D. E. Jablonski und G. W. Leibniz, Jurjew 1899; C. J. Gerhardt (Hg.), Der Briefwechsel von Gottfried Wilhelm Leibniz mit Mathematikern, Berlin 1899; Gottfried Wilhelm LeIBNIZ, Philosophischer Briefwechsel, Darmstadt 1926.

4 A. J. Q. Beuchot (ed.), Oeuvres de Voltaire, T. LI-LXX, Correspondance, T. I-XX, Paris 1830-1834.

5 Friedrich Burckhardt (Hg.), Aus Tycho Brahe's Briefwechsel, Basel 1887; Tycho Brahe, Opera omnia, I, Epistolae astronomicae, Hauniae 1913; Tycho BraHe, Opera omnia, VI-VIII, Epistolae astronomicae, T. I-III, Hauniae 1919-1925.

6 Carl von Linné, Bref och skrifvelser, Afd. 1, Del. 1-8, Stockholm 1907-1922.

7 Adolf Patera (ed.), Jana Amosa Komenského korrespondence, Praha 1892; Ján Kvačala (ed.), Korrespondence Jana Amosa Komenského, 2 sv., Praha 1898-1902. 
Podobně ani republika učenců není novým tématem. Mezinárodní historiografie se již od 60. let věnovala intenzivnímu zkoumání tohoto virtuálního společenství, jeho struktur, praxí, sociálních obsahů, či proměn jeho sebeprezentace. Stačí zde zmínit alespoň vlivné práce Krzysztofa Pomiana, Fritze Schalka, Wilhelma Kühlmanna, Marca Fumaroliho, Françoise Waquetové a Hanse Botse, či kritiku jejich prací a reinterpretaci republiky učenců z pera Herberta Jaumanna. ${ }^{8}$ Jedna významná současná definice republiky učenců ji nazývá sítí či konglomerátem sítí založeným na komunikaci prostřednictvím korespondenční výměny. ${ }^{9}$ Není sporu o tom, že snaha o popis společenství vzdělanců je tu ovlivněna naší současnou zkušeností s komunikačními a sociálními sítěmi, včetně té světové označované www.

\section{Digitální možnosti zpřístupnění velkého množství dat a metadat}

Teprve s rozvojem počítačových databází, různých digitálních nástrojů a se stále větším množstvím katalogů korespondence a digitálních edic korespondence online je možné uvažovat o zpracování a zpř́istupnění velkého objemu dat, jehož prohledávání a zkoumání bylo dříve pro jedince jen stěží představitelné.

Holandský badatel Dirk van Miert odhaduje, že z období raného novověku dnes máme k dispozici zhruba jeden až dva miliony dopisů psaných učenci, které jsou roztroušeny ve fondech stovek knihoven a archivů v Evropě i mimo ni. ${ }^{10}$ Nové digitální technologie přitom vyzývají ke zpracování tohoto roztroušeného pramenného bohatství, které by nejen zajistilo jeho digitální archivaci a zpř́istupnění, ale bylo by impulsem k novému syntetizujícímu promýšlení evropských dějin vzdělanosti, intelektuálních dějin i fenoménu republiky učenců.

Klíčovým obdobím, kdy vzniká paralelně několik databázových projektů zaměřených z větší části na korespondenci učenců, byla první dekáda 21. století. Za průkopnický projekt je možné považovat oxfordský Electronic Enlightenment Project, jehož idea se zrodila již v roce 1995, ale plně se rozběhl až na počátku nového století. ${ }^{11}$ Databáze zahrnuje metadata a plné texty převážně vydané korespondence z období od počátku 17. století do konce

8 Krzysztof Pomian, Utopia i poznanie historyczne. Ideal République des Lettres i narodziny postulatu obiektywności historyka, Studia Filozoficzne 40, 1965, s. 21-76; Fritz ScHALK, Von Erasmus ‘ Res publica literaria zur Gelehrtenrepublik der Aufklärung, in: týž (Hg.), Studien zur französischen Aufklärung, Frankfurt am Main 1977, s. 143-163; Wilhelm KüHLmann, Gelehrtenrepublik und Fürstenstaat. Entwicklung und Kritik des deutschen Späthumanismus in der Literatur des Barockzeitalters, Tübingen 1982; Marc FuMAROLI, La république des lettres, Diogène 143, 1988, s. 131-150; Hans Bots - Françoise WaQuet (eds.), Commercium Litterarium. La communication dans la république des lettres / Forms of Communication in the Republic of Letters 1600-1750, Amsterdam - Maarssen 1994; Hans BoTs - Françoise WAQUET, La République des Lettres, Paris-Bruselles 1997; Herbert Jaumann, Das Projekt des Universalismus. Zum Konzept des Respublica litteraria in der frühen Neuzeit, in: Peter-Eckhard Knabe - Johannes Thiele (Hg.), Über Texte. Festschrift für Karl-Ludwig Selig, Tübingen - Stauffenburg 1997, s. 149-162; Herbert JAUMANN, Respublica literaria / Republic of Letters. Concept and Perspectives of Research, in: Anthony Grafton - Herbert Jaumann (Hgg.), Die europäische Gelehrtenrepublik im Zeitalter des Konfessionalismus. The European Republic of Letters in the Age of Confessionalism, Wiesbaden 2001, s. 11-19.

9 Dirk VAn Miert, What was the Republic of Letters? A brief introduction to a long history (1417-2008), Groniek 204/205, 2016, s. 269-287, zde s. 270.

10 D. VAN MierT, What was the Republic of Letters?, s. 284.

$11<\mathrm{http}: / /$ www.e-enlightenment.com/> [cit. 30. 9. 2018]. 
19. století; v současnosti se jedná o více než 77000 dopisů a přes 10000 biogramů. Jistou geograficko-etnickou nevyváženost a zaměření na velké západoevropské národy a velké postavy osvícenské epochy prozrazují statistické údaje, podle kterých více než polovinu všech biogramů tvoří Francouzi a Angličané, Američanů je tu zastoupeno více než 1300, Němců však jen 300, což je srovnatelné se zastoupením Italů, Holand’anů 130, Rusů 56 a Španělů něco málo přes 30 . Jedná se o placenou databázi, která umožňuje předplatitelům prohledávání údajů o korespondentech, dopisech a pramenech.

Holandský projekt Circulation of Knowledge and Learned Practices in the Seventeenth-Century Dutch Republic byl iniciován roku 2008 haagským Huygens Institute ING. ${ }^{12}$ Databáze zahrnuje přes 20000 dopisů, které tvoří korespondenční soubory devíti holandských nebo v Holandsku působících učenců včetně Descarta, Grotia, Christiana a Constantina Huygensů a dalších. V rámci projektu bylo vyvinuto tzv. virtuální výzkumné prostředí (virtual research environement - VRE) nazývané ePistolarium, které umožňuje uživatelům fulltextově prohledávat celý korpus, nebo vybírat dopisy podle metadat a zmiňovaných osob. Dále je možné $\mathrm{v}$ tomto prostř̌edí vytvářet různé vizualizace, analyzovat textový korpus z hlediska klíčových slov, uplatňovat metody topic modelingu a získávat kvantitativní údaje (počet korespondentů, frekvence korespondenční výměny, délka dopisů, užívané jazyky) i kvalitativní informace (témata dopisů, typy učenců, rétorika dopisů).

Ve stejném roce 2008 vznikl na University of Stanford americký projekt Mapping the Republic of Letters, ${ }^{13}$ který se zaměřuje, vedle dalších témat jako je cestování (grand tour) a publikování, na korespondenci velkých postav jednak osvícenské epochy (napr. Voltaire, D’Alambert, Condorcet, Locke nebo Franklin), ale i dřívějších období (Galileo Galilei, Athanasius Kircher). Stanfordský projekt se od počátku intenzivně zabýval možnostmi mapových a dalších vizualizací (grafy, tabulky, galerie) a vyvinul za tímto účelem digitální nástroj Palladio, který je volně př́ístupný online. ${ }^{14}$

Další evropský projekt s názvem Frühneuzeitliche Ärztebriefe des deutschsprachigen Raums (1500-1700) byl zahájen roku 2009 na Ústavu pro dějiny medicíny Univerzity Würzburg (nyní je řízen Bavorskou akademií věd) a jeho trvání je plánováno na patnáct let. ${ }^{15}$ Databáze v současnosti obsahuje metadata cca 25000 dopisů, vybrané listy jsou pak $\mathrm{k}$ dispozici i fulltextově a s naskenovanými originály. Databáze umožňuje jen prohledávání, nemá $\mathrm{k}$ dispozici žádné další digitální nástroje využitelné pro analýzu dat či jejich vizualizaci.

Stejně jako würzburský projekt byl roku 2009 založen interdisciplinární výzkumný projekt Cultures of Knowledge: An Intellectual Geography of the Seventeenth-Century Republic of Letters při Oxfordské univerzitě. ${ }^{16}$ Projekt si vytyčil jako svůj hlavní cíl studium raně novověkých učeneckých korespondenčních sítí a různých aspektů intelektuální komunikace. Mimo jiné byla $\mathrm{v}$ jeho rámci uspořádána série workshopů a konferencí v Praze, Krakově, Budapešti a Oxfordu, které mapovaly různé intelektuální proudy 16. a 17. století, zejména encyklopedismus, školské reformy, irénismus a milenarismus. Zároveň se projekt ve své první fázi zaměřil na zpracování šesti korespondenčních souborů

\footnotetext{
$<$ http://ckcc.huygens.knaw.nl/> [cit. 30. 9. 2018].

$<$ http://republicofletters.stanford.edu/> [cit. 30. 9. 2018].

$4<$ https://hdlab.stanford.edu/palladio/> [cit. 30. 9. 2018].

$5<$ http://www.aerztebriefe.de/> [cit. 30.9. 2018].

$16<$ https://cofk.history.ox.ac.uk/> [cit. 30. 9. 2018].
} 
učenců Johna Aubreyho, Edwarda Lhwyda, Martina Listera, Johna Wallise, Samuela Hartliba a Jana Amose Komenského. Metadata jejich dopisů byla zpracována spolu s metadaty katalogu korespondence Bodleyovy knihovny (Bodleian Library) a vytvořila tak základ databáze Early Modern Letters Online (EMLO). Ve svých dalších fázích a se změněným názvem Cultures of Knowledge: Networking the Republic of Letters, 1550-1750 ${ }^{17} \mathrm{se}$ projekt soustředil zejména na rozšíření prosopografických metadat a dat o historických geografických názvech vycházejících ze zpracovávaných korespondenčních souborů. Zároveň integroval do databáze velké soubory dat $\mathrm{z}$ vydaných edic raně novověké učenecké korespondence. V současné době databáze EMLO představuje vyhledávací pomůcku a zároveň editační interface pro popis raně novověké korespondence (obr. 1). ${ }^{18}$ Zahrnuje 131686 dopisů, 106 katalogů (většinou korespondenčních souborů jednotlivců, $\mathrm{z}$ větší části učenců a literátů, rovněž však několik souborů institucionální provenience - zejména vědeckých společností či církví a již zmiňovaný soubor 48691 dopisů chovaných v Bodleian library), ${ }^{19}$ zahrnuje prameny z 356 knihoven, archivů a muzeí, údaje o 23232 osobách, které jsou bud' pisateli dopisů, jejich př́ijemci nebo jsou v dopisech zmiňovány. Těžiště databáze spočívá v 17. století, podstatně méně je zastoupeno století 16. a 18., což dobře dokumentuje srovnání jednotlivých půlstoletí (1500-1550: 62 dopisů, 1551-1600: 5504, 1601-1650: 40 059, 1651-1700: 38 681, 1701-1750: 22 283, 1751-1800: 6 533).

Výše uvedené databázové projekty zpracovávající raně novověkou učeneckou korespondenci nejsou jediné, které v uplynulých dvou desetiletích vznikly. Existuje celá řada podobných projektů, od pouhých digitálních soupisů či katalogů, přes projekty s ambicí využívat sofistikovaným způsobem zpracovaná metadata, po ty, které do databází zapojují fulltextově prohledávatelné digitální edice. S přibývajícími projekty vznikla potřeba jejich koordinace minimálně v evropském měřítku. S tímto cílem byl roku 2014 iniciován čtyřletý evropský projekt $\mathrm{v}$ rámci programu COST Action (European Cooperation in Science and Technology) s názvem Reassembling the Republic of Letters, 1500-1800: A digital framework for multi-lateral collaboration on Europe's intellectual history (obr. 2). ${ }^{20}$ Jak je patrné již z názvu, v rámci projektu byly diskutovány možnosti vytvoření nadnárodní digitální infrastruktury, která by byla open-access a umožnila by shromáždit data a metadata ohledně učené korespondence zpracovávané v rámci různých národních, regionálních a tematických projektů do jedné standardizované databáze, pracovně nazývané EULO (European Letters Online). Projektu se účastnilo 31 evropských zemí a Izrael, Spojené státy americké prostřednictvím Stanfordské univerzity pak jako partnerská země a jednotliví badatelé i z Turecka a Kanady. Na práci se podíleli odborníci ze čtyř různých profesních skupin - badatelé (většinou působící na univerzitách či akademických pracovištích), knihovníci a archiváŕi, IT specialisté a digitální designéři. Tito odborníci se spolu setkávali v rámci pěti pracovních skupin zaměřených na metody digitálního zpracování geografických a temporálních dat, zpracování prosopografických dat a modelování

\footnotetext{
$<\mathrm{http}: / /$ www.culturesofknowledge.org/> [cit. 30. 9. 2018].

$<$ http://emlo.bodleian.ox.ac.uk/> [cit. 30.9. 2018].

19 Ze známějších osobností, jejichž korespondenční soubory byly pro databázi zpracovány, je možné výběrově jmenovat Pierra Baylea, Jakoba Böhma, Tychona Brahe, Reného Descarta, Leonharda Eulera, Huga Grotia, Samuela Hartliba, Thomase Hobbese, Christiaana a Constantijna Huygensovi, Johannesa Keplera, Athanasia Kirchera, Marina Mersenna, Henryho Oldenburga, Martina Opitze, Blaise Pascala, Nicolase-Clauda Fabriho de Peiresc, Josepha Justa Scaligera, Philipa Sidneyho, Barucha Spinozu či Juana Luise Vivese.

$20<\mathrm{http}: / /$ www.republicofletters.net/> [cit. 30. 9. 2018].
} 
sociálních a komunikačních sítí, na analýzu textových souborů a tematické modelování (topic modeling), na problematiku soupisů epistolárních knihovních a archivních fondů a standardizovaný popis jednotlivých dopisů, na výměnu dat a strategické plánování a na metody digitální vizualizace zpracovávaných dat a metadat. $\mathrm{V}$ rámci projektu se konalo několik konferencí, workshopů a letních škol, mladší badatelé měli možnost využít krátkodobé badatelské pobyty v účastnických zemích. Za Českou republiku se do aktivit projektu zapojili pracovnice a pracovníci Filosofického ústavu AV ČR, Historického ústavu AV ČR, Knihovny Akademie věd a Knihovny Národního muzea.

\section{Komenského korespondence v síti}

Zaměřím se nyní na dva projekty, s nimiž spolupracuje Oddělení pro komeniologii a intelektuální dějiny raného novověku Filosofického ústavu AV ČR. První z nich je zmiňovaný oxfordský projekt Cultures of Knowledge a databáze Early Modern Letters Online, která vznikla $\mathrm{v}$ jeho rámci. Tým Filosofického ústavu spolupracoval s oxfordským týmem od samého počátku projektu, v letech 2009-2010 se podílel na organizaci workshopů v Praze, Krakově a Budapešti a na prŕípravě velké konference v Oxfordu. Zejména však pražský tým připravil pro databázi EMLO metadata korespondence Jana Amose Komenského, ${ }^{21}$ později menší soubory korespondence opavského rodáka a basilejského teologa Amanda Polana z Polansdorfu (325 dopisů), ${ }^{22}$ vratislavského lékaře a vydavatele časopisu Miscellanea curiosa medico-physica Philippa Jakoba Sachse z Löwenheimu (143 dopisů), ${ }^{23}$ spolupracoval na př́ípravě metadat souboru korespondence jezuitského polyhistora Athanasia Kirchera (2 741 dopisů ${ }^{24}$ a zprostředkoval metadata vytvořená na základě Hrubého edice korespondence českých studentů na protestantských školách (290 dopisů) z Digitální knihovny Filosofické fakulty Masarykovy univerzity. ${ }^{25}$

Pokud jde o katalog Komenského korespondence, ${ }^{26}$ projekt umožnil získat kvalitní skeny veškeré dochované korespondence odeslané i přijaté uložené v 36 archivech a knihovnách ve 32 zemích (obr. 3). V rámci projektu došlo i k některým objevům dosud neznámých dopisů. Zejména se jedná o Komenského dopis Samuelu Hartlibovi, který byl dosud znám

21 Jiří Beneš - Marta BečKová - Markéta Klosová - Lenka ŘezníkovÁ - Vladimír UrbÁneK - Kateřina HorNíčKOVÁ - Iva LelKovÁ and Cultures of Knowledge, The Correspondence of Jan Amos Comenius, Cultures of Knowledge, <http://emlo-portal.bodleian.ox.ac.uk/collections/?catalogue=jan-amos-comenius $>$ [cit. 30. 9. 2018].

22 Iva Lelkoví, The Correspondence of Amandus Polanus of Polansdorf, Cultures of Knowledge, <http://emlo-portal.bodleian.ox.ac.uk/collections/?catalogue=amandus-polanus $>$ [cit. 30. 9. 2018].

23 Iva LelkovÁ, The Correspondence of Philipp Jakob Sachs von Löwenheim, Cultures of Knowledge, <http:// emlo-portal.bodleian.ox.ac.uk/collections/?catalogue=philipp-jakob-sachs-von-lowenheim $>$ [cit. 30. 9. 2018].

24 Mapping the Republic of Letters, The Correspondence of Athanasius Kircher, Cultures of Knowledge, <http:// emlo-portal.bodleian.ox.ac.uk/collections/?catalogue=athanasius-kircher $>$ [cit. 30. 9. 2018]. Iva Lelková spolupracovala na databázi Kircherovy korespondence již během svého pobytu ve Stanfordu a pak opět během její implementace do EMLO v rámci spolupráce mezi Oxfordem a FLÚ AV ČR.

25 Cultures of Knowledge and the Digital Library of the Faculty of Arts, Masaryk University, Brno, The Correspondence of Czech Students at Protestant Universities, in: Early Modern Letters Online, Cultures of Knowledge, <http://emlo-portal.bodleian.ox.ac.uk/collections/?catalogue=czech-students-hruby $>$ [cit. 30. 9. 2018]. Metadata byla převzata z edice František HrubÝ - Libuše UrbánKovÁ-HrubÁ (edd.), Étudiants tchèques aux écoles protestantes de l'Europe occidentale à la fin du 16e et au début du 17e siècle, Brno 1970.

26 Viz pozn. 21. 
jen z nedatovaného výtahu uloženého v Knihovně Národního muzea. Daleko obsáhlejší dobový opis tohoto dopisu datovaný 9 . ledna 1634 objevila Iva Lelková v basilejské univerzitní knihovně. ${ }^{27}$ Mimo jiné dopis přináší detailní informace o Komenského plánu tříd a učebnic pro latinskou školu, $v$ lecčem odlišný od dosud známých návrhů z jeho publikovaných děl. Databáze Komenského korespondence dnes obsahuje 571 položek a je výbornou pomůckou pro práci na nové kritické edici Komenského korespondence, jejíž první díl právě vychází ${ }^{28}$ Metadata Komenského korespondence zahrnují údaje o datech, osobách (odesílatel, prŕjjemce, osoby zmiňované), místech (místo odeslání, místo adresáta), regest, údaje o jazyku dopisu, incipit, explicit, údaje o dochování a uložení, poznámky, sken originálu (rukopisu nebo starého tisku), prípadně i edice.

Co nabízí databáze, její různé funkce a nové digitální nástroje z hlediska interpretace Komenského korespondence? Především se bádání otevřely nové možnosti znovu se zabývat Komenského korespondencí $\mathrm{v}$ rámci tehdejší republiky učenců a přesněji vymezit jeho místo i význam jeho díla v tomto virtuálním společenství vzdělanců. Komenský v něm figuruje jako významná postava, kolem níž se točila řada dobových diskusí o tématech, jako byla reforma škol a veškerého dobového vědění, náprava společnosti, či reforma náboženství. Databáze nabízí např́klad možnost srovnávat pro jednotlivé roky statistiku dochované přijaté a odeslané korespondence Komenského a některých jeho klíčových korespondentů (obr. 4). Takové srovnání grafư dvou či více korespondentů umožňuje nejen učinit si představu o dochovanosti dopisủ, ale i formulovat některé badatelské otázky, např. ohledně četnosti výměny dopisů, které je pak samozřejmě třeba specifikovat podrobnějším výzkumem. Díky digitálním nástrojům jako je Palladio lze mapově zobrazit geografickou distribuci Komenského odeslané a přijaté korespondence a srovnat ji s jinými korespondenčními sítěmi 17. století (obr. 5). Pomocí těchto mapových zobrazení pak můžeme lépe formulovat otázky spojené s tématem center a periférií tehdejší republiky učenců. Jakou roli hrály individuální korespondenční sítě v propojování tzv. center a tzv. periférií tehdejšího vědění a v komunikaci mezi nimi? Jak byly navázány na institucionální sítě církevních, řádových, univerzitních či vědeckých společností? V př́ípadě Komenského tak můžeme např́klad sledovat dynamiku vytváření a rozvíjení jeho korespondenčních kontaktů s lokálními učeneckými kruhy v Gdańsku ve 30. a 40. letech 17. století a zároveň jeho integraci do rozsáhlé korespondenční sítě pokrývající půlku Evropy a sahající i do severní Ameriky, budované z Londýna Samuelem Hartlibem. Zatímco Hartlibově korespondenci dominují centra evropské vzdělanosti a komunikační uzly jako Amsterdam, Londýn, Paříž, a teprve pak následují Hamburg, Haag či Oxford, Komenského korespondenci sice právě díky Hartlibovi vévodí Londýn, Gdańsk však předčí Amsterdam a Pařǐž hraje v Komenského korespondenci marginální roli. Srovnání obou těchto převážně protestantských korespondenčních sítí s rozsáhlou korespondenční sítí francouzského minority Marina Mersenna ukazuje podstatné rozdíly. Mersennově síti dominují Paříž, Aix-en-Provence, Řím, Florencie a Haag.

Databáze rovněž umožňuje srovnání osob zapojených do komunikace v rámci jednotlivých korespondenčních sítí. Zatímco Mersennově korespondenci dominují Francouzi

27 Universitätsbibliothek Basel, sign. Frey-Gryn Mscr VII 3, ff. 25r-26r.

28 J. A. Komenský, Epistulae - Korespondence, Pars I, in: Martin Steiner - Tomáš HavelKa - Vladimír Urbánek (edd.), Dílo J. A. Komenského - J. A. Comenii Opera omnia 26/I, Praha 2018. 
v čele s Descartem, následovaní Peirescem, Gassendim a teprve pak Holand'anem Konstantinem Huygensem, v čele Komenského učených korespondenčních partnerů stojí již zmiňovaný polský Němec naturalizovaný v Anglii Samuel Hartlib, slezský filolog Cyprian Kinner či braniborský historiograf Joachim Hübner. Je tedy vidět, že s výjimkou Hartliba, považovaného za předního dobového zpravodajce vědění, si Komenský nejaktivněji dopisoval s osobami spíše lokálního významu, propojenými však často společným studiem na univerzitách, sdílenými přáteli, stejnými mecenáši a společnými intelektuálními zájmy. I v jeho korespondenci se objevují velká jména dobové vědy a vzdělanosti, např. právě matematik, filosof a teoretik hudby Marin Mersenne, astronom Johannes Hevelius, básník Martin Opitz, nebo sekretář anglické Royal Society Henry Oldenburg, spíše však okrajově.

Vedle práce s daty, která lze bezprostředně čerpat z databáze EMLO a využít je pro makroanalýzu, lze na tomto materiálu testovat nové digitální nástroje. To umožňuje zejména již zmiňovaný evropský projekt Reassembling the Republic of Letters. V jeho rámci se ve spolupráci s IT specialisty a počítačovými grafiky z Polytechniky v Miláně podařilo vytvořit určitý prototyp vizualizačního nástroje, ${ }^{29}$ který umožňuje kombinovat data ohledně korespondence a data ohledně mobility konkrétního jedince, v našem případě Komenského (obr. 6). Zatímco v pravé části se pomocí mapy vizualizují cesty Komenského a barevně označená místa ukazují, kam adresoval či odkud přijímal korespondenci, v levé části graf s dvěma osami (vodorovná je časová, svislá zahrnuje geografické názvy všech míst, kde Komenský pobýval nebo kudy cestoval) zobrazuje jednak nemapový graf jeho cest spolu $\mathrm{s}$ délkou pobytu $\mathrm{v}$ jednotlivých místech a opět barevnými body označená data pro odeslanou (červené body) a přijatou korespondenci (modré body). Obě části vizualizace jsou interaktivní, takže uživatel může pohybovat kurzorem v mapové části či v grafu a sledovat pohyb i v druhé části. Z funkce nad grafem je možné si vybrat i kratší časový úsek deseti let a vidět pro zvolené období Komenského itinerář i data pro jeho korespondenci ve větším detailu.

Pomocí tohoto nástroje lze tedy ukázat, v jakém vztahu je mobilita určité osoby k proměnám jejích korespondenčních kontaktů. Abych uvedl př́íklad, Komenského itinerář po návratu z Anglie na kontinent v červnu 1642 odráží do značné míry předchozí korespondenční kontakty s amsterdamskými vzdělanci Johannem Moriaenem a Godfriedem Hottonem, ale také zájem o jeho dílo ze strany osob, s nimiž si nikdy nedopisoval, nicméně o setkání s nimi usiloval (jako byl Descartes), které však jeho spisy četly díky zprostředkování osob, s nimiž si dopisoval, ale nikdy osobně nesetkal (jako byl Mersenne). Vizualizace může také pomoci formulovat otázky ohledně frekvence korespondenčních kontaktů v určitém období ve vztahu k regionu nebo městu, v němž se Komenský zdržoval, a dostupnosti či propojení onoho místa s metropolemi vědění. Tak např. je pozoruhodné, že listovní spojení Lešna a Londýna bylo ve třicátých letech častější než korespondenční výměna mezi Elbingem a Londýnem po roce 1642, přestože poštovní spojení bylo z baltských prrístavů jednodušší než z polského vnitrozemí. Vysvětlení faktu, že Komenský v tomto období

29 Prototyp vizualizačního nástroje vznikl během intenzivního soustředění „design sprint“ ve dnech 4.-8. dubna 2017. Na jeho vzniku se pod vedením Vladimíra Urbánka podíleli Roberto Evangelista, Magnus Ulrich Ferber, Beatrice Gobbo a Alex Piacentini. Autorem prototypu je Alex Piacentini. Během soustředění vznikla i řada dalších vizualizací vztažených k tématu Correspondences over itineraries. Ty jsou dostupné spolu s podrobným popisem projektu na <http://www.republicofletters.net/wp-content/uploads/2018/04/2017_Design_Sprint_02 _Final-Report_def.pdf $>$ [cit. 30.9.2018]. 
daleko intenzivněji korespondoval s Amsterdamem a Švédskem než s přáteli v Londýně, je proto třeba hledat v jejich proměňujících se vztazích, nikoli ve vnějších faktorech.

Zmíněný vizualizační nástroj by samozřejmě bylo vhodné otestovat na jiných souborech dat, např. na údajích o peregrinujících studentech, zápisech ve štambuších či na jiných korespondenčních souborech vzešlých z činnosti vysoce mobilních osob. Jeho možné využití pro zkoumání pohybů a literární tvorby české pobělohorské exilové inteligence se př́mo nabízí.

\section{Bohemikální data, bohemikální témata?}

Databáze EMLO zatím nemůže sloužit ke smysluplnému výzkumu dat zaměřených na geografický horizont učenecké korespondence bohemikální provenience a na zapojení českých zemí do evropských korespondenčních sítí. To je dané do značné míry způsobem, jakým jsou do databáze získávána metadata. Přesto databáze EMLO obsahuje relativně početnou skupinu listů, u nichž jsou české země bud' místem odeslání či místem přijetí korespondence. Ta je svým počtem srovnatelná jen s německou databází lékařské korespondence. Přesto je naše představa o zapojení českých zemí do evropské republiky učenců zatím jen kusá a nejasná.

Pokud jde o geografická data, následující statistické údaje získané díky funkcím, které databáze umožňuje, dávají dobrou představu o jejích limitech.

České země jako místo odeslání: 717 výskytů (1547-1678/1757) / místo přijetí: 373 výskyty $(1575-1667)^{30}$

Praha jako místo odeslání: 431 výskytů (1547-1657) / místo přijetí: 357 výskytů (1575-1665)

Benátky nad Jizerou jako místo odeslání: 62 (1599-1600) / místo přijetí: 5

Rosice u Brna jako místo odeslání: 46 (1592-1624)

Olomouc jako místo odeslání: 19 výskytů

Dopisy z českých zemí do Itálie: 177 dopisů (1603-1678)

Dopisy z českých zemí do německých zemí: 75 dopisů (1600-1665)

Dopisy z českých zemí do českých zemí: 54 dopisů (1600-1620)

Dopisy z českých zemí do Nizozemí: 26 dopisů (1578-1665)

Dopisy z českých zemí do Rakous: 12 dopisů (1597-1605)

Dopisy z českých zemí do Francie: 2 dopisy $(1606,1620)$

Dopisy z českých zemí do Švýcarska: 3 dopisy $(1599,1600)$

Poslední údaj o Švýcarsku je však dokladem toho, že uživatel databáze musí být ostražitý a se statistickými údaji, které se dají lehko získat, musí nakládat kriticky. Údaj o Švýcarsku se totiž vztahuje ke korespondenci adresované Polanovi z Polansdorfu a odráží fakt, že jen u tří dopisů je uvedena adresa př́ijemce (adresa patrně chybí v rukopisném či tištěném

30 Pro srovnání Francie je uvedena jako místo odeslání u 13842 dopisů, Anglie u 30258 dopisů, Nizozemí u 27641 dopisů, Polsko u 1245 dopisů, Rakousko jen u 468 dopisů, Śpanělsko u 289 dopisů a Uhry u pouhých 49 dopisů. Těchto pár statistických dat ukazuje, že v databázi jsou jednotlivé země zastoupeny velmi nerovnoměrně, nicméně stále podstatně lépe než v databázi Electronic Enlightenment. 
prameni). Polanus však ve skutečnosti figuruje v databázi jako př́ijemce 40 dopisů z českých zemí a statistický údaj by tedy měl být $\mathrm{v}$ tomto smyslu opraven. Ze stejného důvodu ze statistiky vypadly i dopisy adresované Theodoru Bezovi do Ženevy a listy Tadeáše Hájka z Hájku s Tychonem Brahe. To je důvod, proč údaj o Dánsku př̀i statistickém průzkumu není $\mathrm{k}$ dispozici.

Uživatel by rovněž měl mít na paměti, že celkem 540 dopisů odeslaných z českých zemí (z celkového počtu 717) pochází jen ze čtyř katalogů zahrnutých do databáze - tedy z korespondence Keplerovy, Kircherovy, Braheho a z Hrubého edice korespondence českých studentů. ${ }^{31}$

Pro úplnost uved'me ještě údaje o aktérech bohemikální korespondence v databázi EMLO. O něco více než polovinu dopisů (377) napsali Johannes Kepler (128), Tycho Brahe (98), Karel st. ze Žerotína (84), Marek Marci (36), Gottfried Alois Kinner z Löwenthurnu (31). K nejčetněji zastoupeným adresátům dopisů z českých zemí patř́ Athanasius Kircher (156), Amand Polanus z Polansdorfu (40), Johann Jakob Grynaeus (40), Tycho Brahe (29), Johannes Kepler (28) a královna Alžběta Stuartovna (21).

Dosud rovněž selhává snaha učinit si alespoň rámcovou představu o klíčových tématech probíraných v dopisech odeslaných z českých zemí. Klíčová slova zatím obsahuje jen pár katalogů (Komenský a Kepler k nim patr̂́í), a tak není divu, že při prohledávání dopisů psaných v českých zemích mezi klíčovými slovy vysoce dominuje astronomie (83 dopisů), před chronologií (28), astrologií (25), teologií (19), knihami (15) a politikou (10).

Srovnáme-li prohledávací funkce databáze EMLO s funkcemi výše zmíněné databáze Frühneuzeitliche Ärztebriefe des deutschsprachigen Raums (1500-1700), vyniknou výhody druhé z nich zvláště v souvislosti s českým materiálem. Databáze lékařské korespondence má důsledně vyplňovanou rubriku klíčových slov i regest, takže je možné při hledání kombinovat např. místo odeslání (Praha je v databázi zastoupena jako místo odeslání ve 429 př́padech) s klíčovými slovy (např. Epidemie, Hippokrates nebo Mathematik).

\section{Další možnosti}

Nové digitální nástroje, experimentování s vizualizacemi i rozvoj standardizované a dlouhodobě udržitelné evropské infrastruktury - zmiňované databáze EULO - mohou pro bádání o tomto tématu, i obecně pro rozvoj dějin vzdělanosti a intelektuálních dějin, vytvořit velmi příznivé podmínky. Pokud však česká historiografie chce v budoucnu hrát při tvorbě této či jiných podobných databází významnějš́ roli, bude muset usilovat nejen o začlenění více korespondenčních souborů bohemikální provenience (namátkou napřr. metadat korespondence Tadeáše Hájka z Hájku, Žerotínovy či Budovcovy korespondence, korespondence Bohuslava Balbína), nýbrž i o aktivnější dialog s IT specialisty a o rozvoj historicky orientovaných digital humanities.

31 Cf. $<$ http://emlo.bodleian.ox.ac.uk/forms/advanced?pla_ori_name=Czech+Republic $>$ [cit. 30. 9. 2018]. Cf. rovněž F. HRUBÝ - L. URBÁNKová-HrubÁ (edd.), Étudiants tchèques. 


\section{Obrazová příloha}

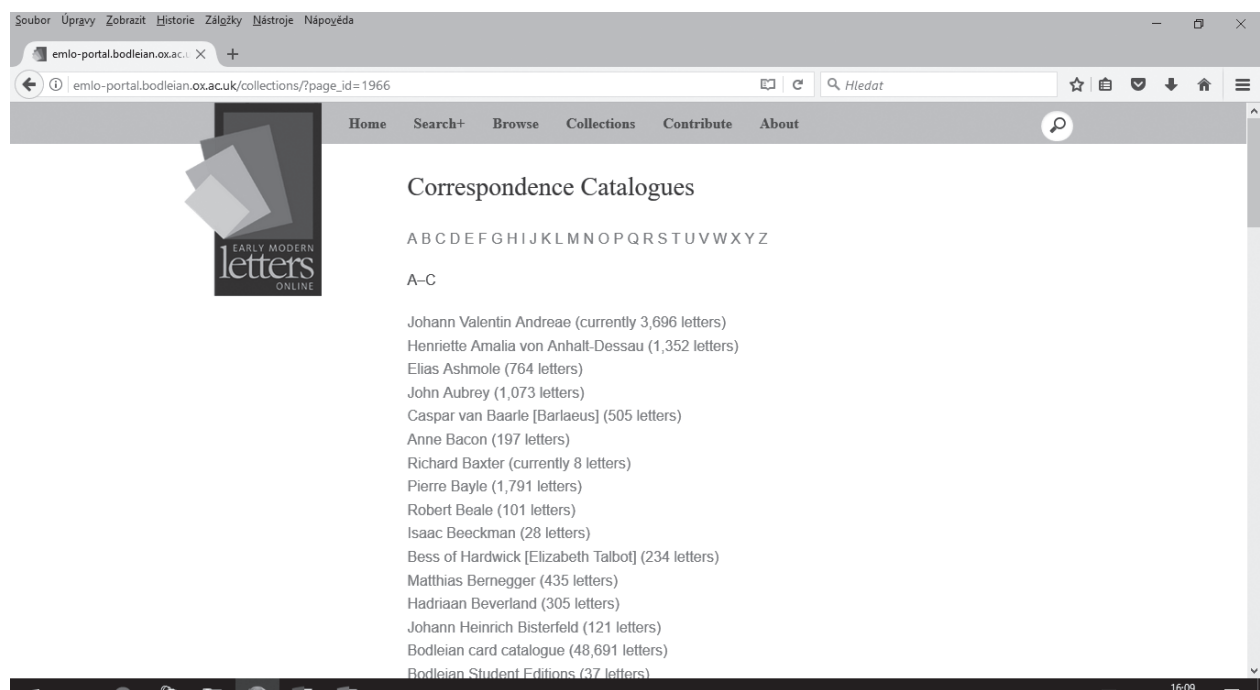

* $\square$ 巳

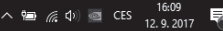

Obr. 1: Databáze EMLO - seznam katalogů korespondence

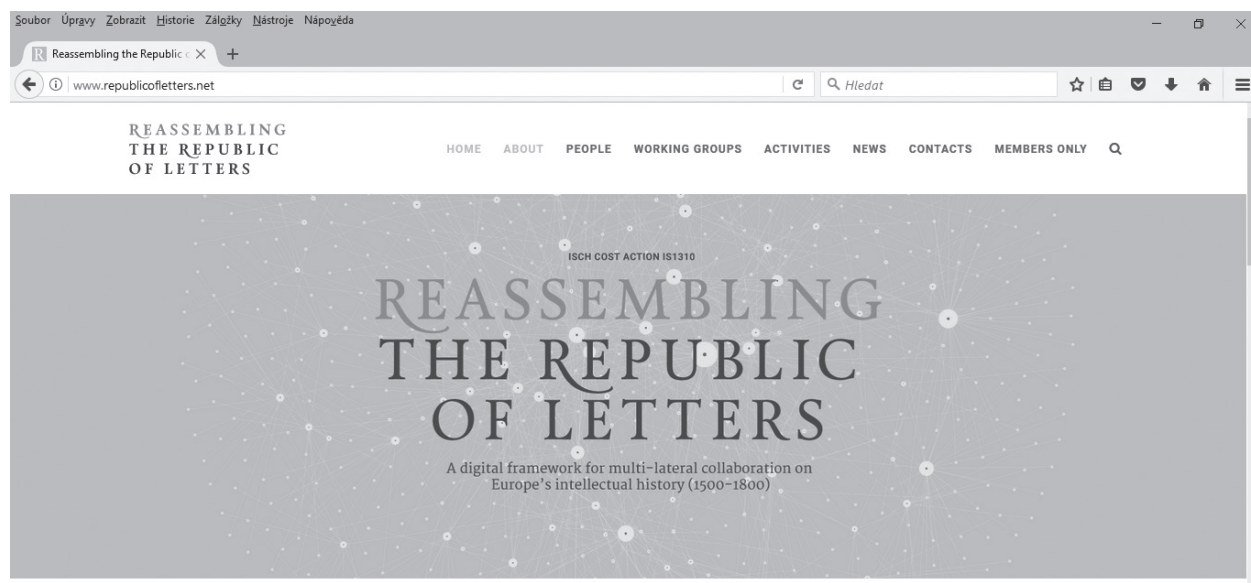

*

Obr. 2: Webová stránka projektu Reassembling the Republic of Letters 


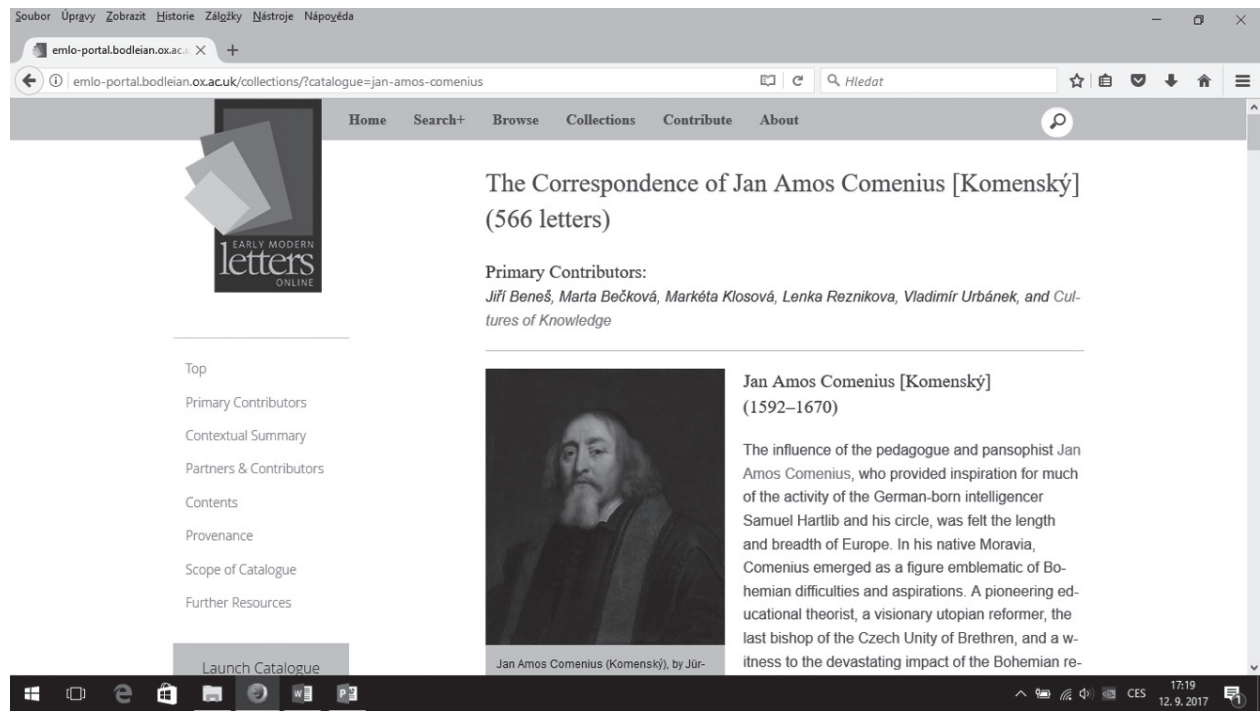

Obr. 3: Databáze EMLO - katalog korespondence J. A. Komenského

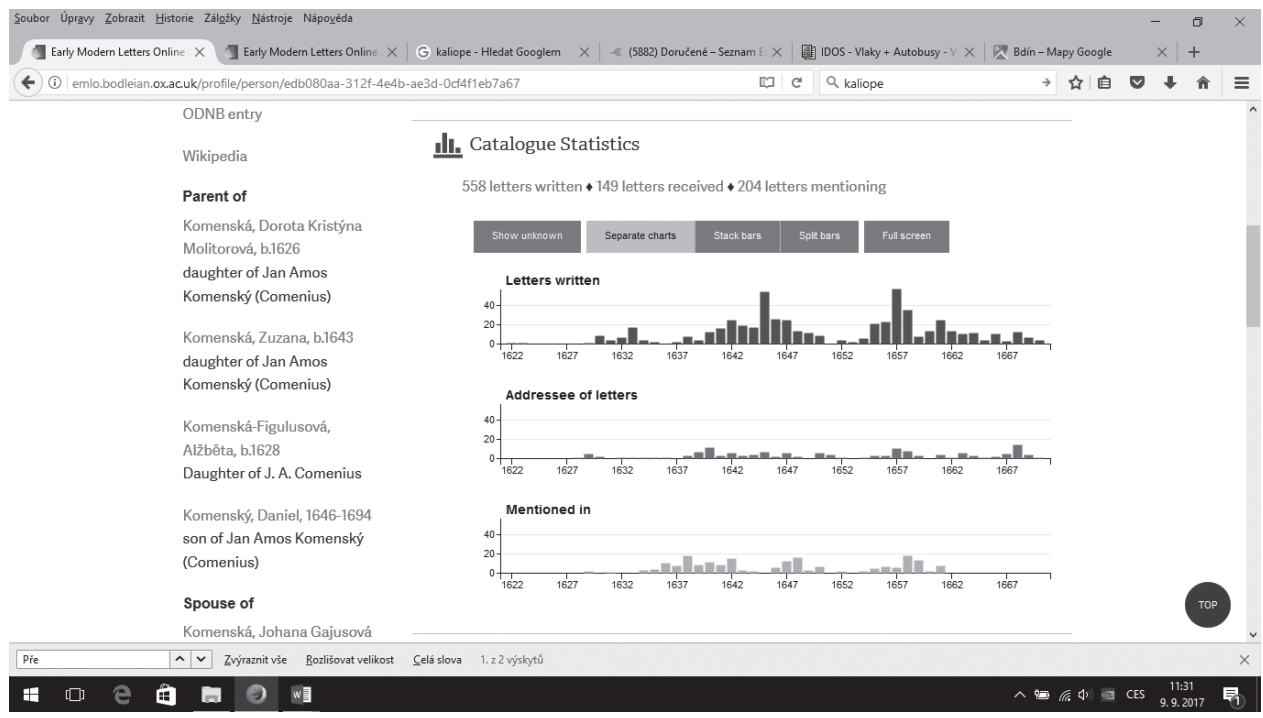

Obr. 4: Databáze EMLO - statistika četnosti Komenského dopisů pro jednotlivé roky 


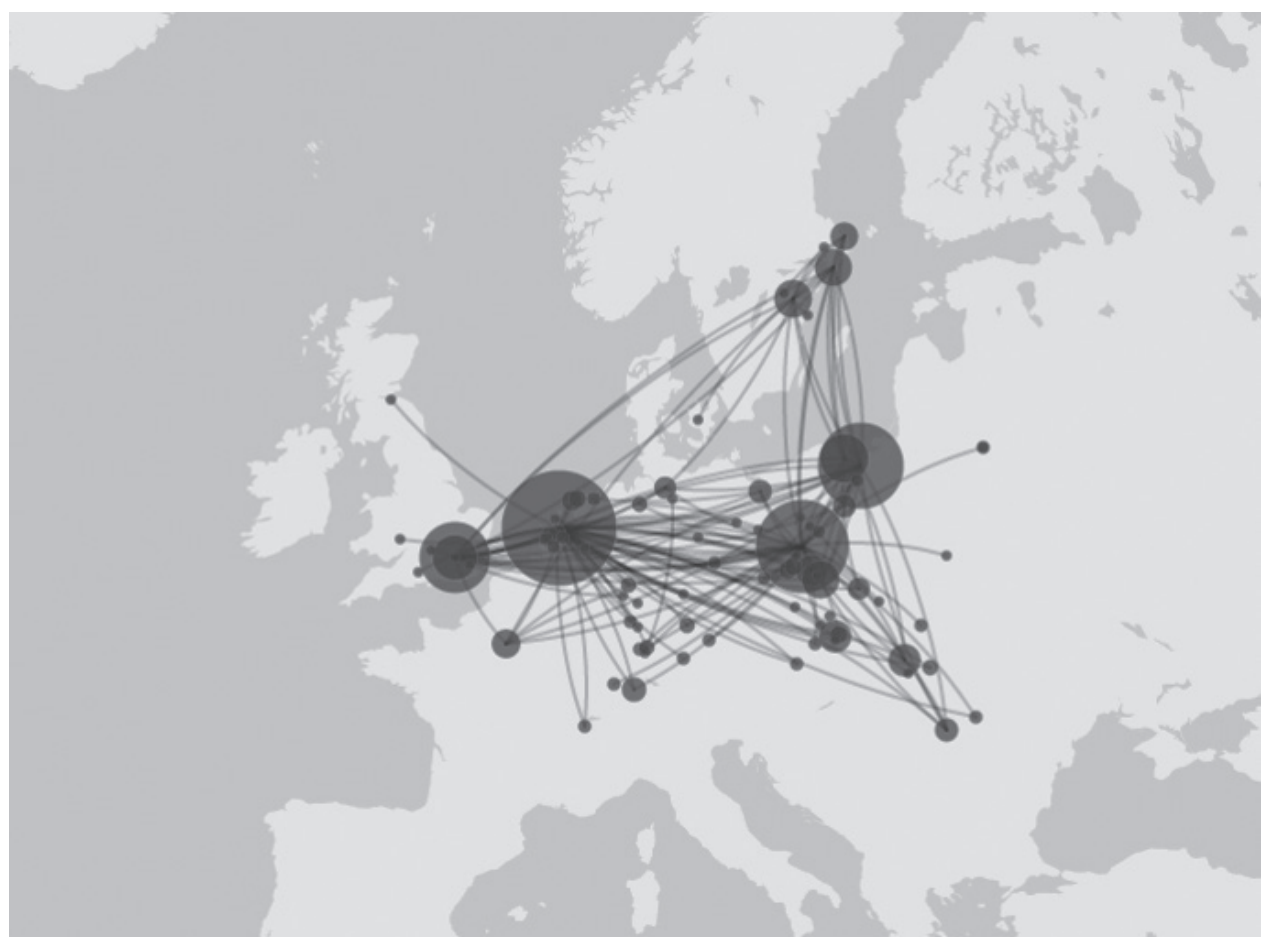

Obr. 5: Geografická distribuce Komenského korespondence

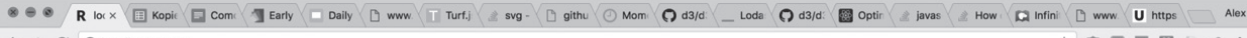
$\leftarrow$ C (1) localhost:8080

Itinerant lorem ipsum Comenuis back A B C D E F $G 1645$

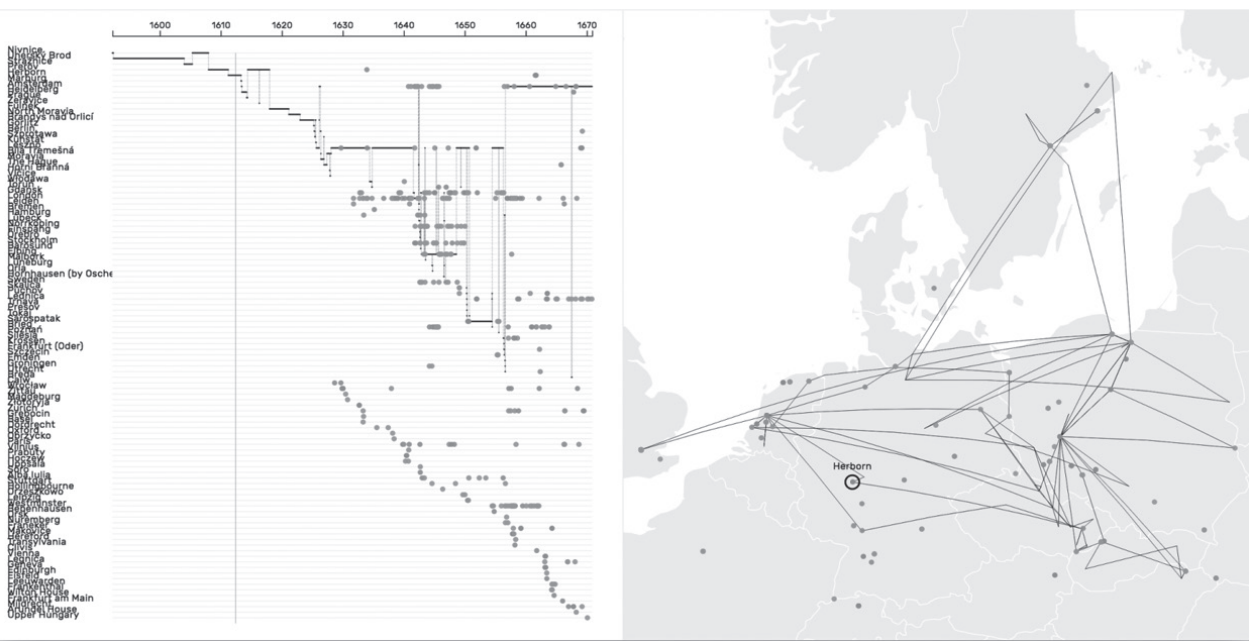

Obr. 6: Prototyp vizualizačního nástroje znázorňujícího Komenského cesty a korespondenci 


\title{
VLADIMÍR URBÁNEK
}

\section{Die frühneuzeitliche Gelehrtenrepublik und das Web: digitale Untersuchungsmethoden gelehrter Korrespondenznetzwerke}

\author{
ZUSAMMENFASSUNG
}

Der Beitrag macht mit internationalen Projekten bekannt, die in den letzten Jahren mittels sophistischer Datenbanken und verschiedener digitaler Instrumentarien umfangreiche, mit der Gelehrtenkorrespondenz des 16.18. Jahrhunderts und dem Phänomen der Gelehrtenrepublik verbundene Daten bearbeiten. Das Augenmerk liegt hier insbesondere auf dem Oxforder Projekt Cultures of Knowledge und Early Modern Letters Online (EMLO) sowie auf dem europäischen Projekt Reassembling the Republic of Letters. An beiden Projekten sind auch tschechische Forscher und Forscherinnen beteiligt, deren hauptsächlicher Beitrag der Katalog der Korrespondenz J. A. Comenius` im Rahmen der EMLO-Datenbank ist. Besagter Katalog wird kurz vorgestellt, bevor sich der Beitrag der Frage widmet, welche Möglichkeiten die neuen digitalen Instrumentarien für eine Interpretation der Comeniusschen Korrespondenz bieten. Im weiteren Teil des Beitrags wird gezeigt, inwieweit Böhmen und Mähren betreffende Daten und implizit auch dementsprechende Themen im Rahmen der EMLO-Datenbank „sichtbar“ sind. Die Nutzung der Datenbank zwecks Erforschung des geographischen Horizonts der Gelehrtenkorrespondenz böhmischer Herkunft und für die Einbeziehung der böhmischen Länder in die europäischen Korrespondenznetzwerke ist bislang nur sehr beschränkt. Im abschließenden Teil des Beitrags werden mögliche Schritte skizziert, mit denen die tschechische Historiographie ihre Zusammenarbeit mit großen internationalen Datenbankprojekten, die nach Schaffung einer standardisierten europäischen Infrastruktur streben, in der Zukunft vertiefen könnte.

Vladimir Urbánek

Filosofický ústav $A V \check{C}$ R, v.v.i., Praha

urbanek@flu.cas.cz

Deutsche Übersetzung Wolf B. Oerter 